\title{
Does the volatility of exchange rates changed under inflation targeting framework in emerging market?
}

\author{
Olfa Manai Daboussi \\ Higher Institute of Management of Tunis-University of Tunis - Tunisia \\ E-mail: manaolfa@yahoo.com
}

\begin{abstract}
This article examines whether or not the adoption of inflation targeting (IT) reduces exchange fluctuation and induced economic growth. We investigate (IT) in emerging market, focusing on the relationship between the exchange rates on inflation and output growth. Our research will focus on the conduct of monetary policy under inflation targeting, with respect to fluctuations in the exchange rates. Based on panel data of 28 emerging countries, of which 13 those have adopted inflation targeting policy over the period 1980-2013. Our results confirm that (IT) regime guarantees the stability of exchange rates, the stability of economic growth and controlling inflation.
\end{abstract}

Keywords: Economic Growth, Emerging Markets, Exchange Volatility, Inflation Targeting.

\section{Introduction}

Recently, inflation targeting has been adopted in many industrial and emerging countries. Since the first adoption of inflation targeting (IT) by the New Zealand (1991), this topic has become very attractive for central banks to give salient regime of floating exchange rates. Since then, the number of emerging countries that have adopted this framework has increased. There are about thirty central banks around the world have adopted this monetary strategy. But it is still difficult to know how fluctuations in the exchange rate must be taken into account in the decisions of the monetary authorities under a regime of inflation targeting. Through the theory, inflation targeting can be characterized by three important elements (Svensson (2010)), namely the announcement of a numerical target, the implementation of a policy based on targeting and forecasting high degree of transparency. Since the 1990s, the pros and cons of adoption of this framework have received much attention. Several studies have shown that the weak impact of exchange rate on domestic prices (Taylor (2000), Gagnon and Ihrig (2004) and Choudhri and Hakura (2006)), is caused mainly by the decline in the exchange rate pass through which is due to the inadequacy of credibility of monetary policy. Rose (2011) noted that the choice of the exchange rate is highly correlated with the choice of monetary policy. He concluded that the views governing the choice of exchange rate regime are strongly held, but the choice has never been explained by economic results found.

Most countries' experiences with inflation targeting seem to have been successful. The economic literature showed that flexible inflation targeting limited the variability of inflation, the variability of output gap and the real exchange rate (Svensson (1997)). In another context, Aghion and al. (2009) showed that exchange rate volatility reduces productivity in developing countries. They concluded that the volatility of exchange rate has a negative impact on the macroeconomic variables in industrialized countries, whereas, volatility is an important effect in emerging countries and least developed countries.
They add that the majority of developing countries have practiced a mixed strategy where inflation targeting central banks responded to both inflation and exchange rate in setting interest rate.

The results found by Lubik and Schorfheide (2007) showed mixed responses. The estimation of Taylor-type rules showed that the monetary authorities in Australia and New Zealand, changes the interest rate as an instrument of monetary policy in response to exchange rate movement. While for the case of Canada, the study of this relationship is not verified. De Mello and Moccero (2010) showed that the interest rate policy rule was formed in the context of the new Keynesian model with structural inflation, output and interest rate. They estimate interest rate policy rules in four emerging market (Brazil, Chile, Colombia and Mexico) adopting inflation targeting and floating exchange rates in 1999. They concluded that the response to expected inflation in Brazil and Chile is very persistent during the post IT period.

In other studies carried out by Pavasuthipaisit (2010), the results show that economies adopting inflation targeting may respond to exchange rate shocks under certain conditions. Finding from their tests give support to the greater sensitivity of commodity inflation targeting countries to exchange rate change.

In the same context, Sek (2008) suggest that the reaction of financial policy to exchange rate shocks have decreased under inflation targeting framework.

Recently, Ghosh (2013) showed that an increase in exchange rate flexibility is found in inflation targeting countries. Petreski (2012) also shows that foreign exchange market interventions Reduces rate volatility, while others showed that this intervention have a limited effect on volatility. Indeed, until now the empirical studies have not provided convincing answers about the role of the exchange rate under IT regime.

Moreover, few studies have analyzed the relationship between inflation targeting and exchange rate despite its importance. As well as the adoption period is insufficient to detect the effect of the exchange rate under (IT) framework. 
Based on these results, we try to establish empirical studies that allow providing robust answers to show the important role of exchange rate under (IT) framework.

Our focus is to analyze the relationship between (IT) framework and variability of exchange rate. Our empirical research is motivated by factors:

Work addressing the relationship between the fluctuation of the exchange rate and inflation targeting in emerging countries, are rare. Then, the conduct of monetary policy in industrialized countries differ in emerging countries either by the operational and institutional frameworks of central banks in the presence of inflation targeting or different level of financial development (Aghion, Bacchetta and Rancière and Rogoff (2009)).

The importance of the role played by the exchange rate in the formulation of monetary policy in emerging markets.

- We follow a panel methodological approach in examining these issues. Most studies that have addressed this issue have been based on individual analyzed using time series analysis. A panel analysis provides some advantages. This method can distinguish two groups of countries, treatment group and control group (Ball and Sheridan (2005), Pétursson (2005)). Treatment groups represented countries that have adopted inflation targeting as the control group which did not adopt inflation targeting.

The aim of this paper is to check whether the adoption of (IT) is effective in reducing the volatility of exchange rates. However, we investigate the volatility of exchange under inflation targeting framework, distinguishing between samples (All countries, ITers and non ITers countries).

Thus, we hope to achieve two goals in this work: one is to contribute to the economic literature on the topic; and the other is to have a more reliable yardstick available in order to explore the effect of exchange rate in emerging countries on the activity during periods of adoption of this framework.

We structure the paper such that section two present empirical analyses and introduces the dataset. In section three gives the estimations results. Section four is devoted to the discussion. Finally, we give the conclusion. The paper has additional tables in the appendices.

\section{Empirical analysis}

\subsection{Theoretical methodology in monetary policy}

Our research will focus on the conduct of monetary policy under inflation targeting, with respect to fluctuations in the real exchange rate. We will use a simple illustrative model, which represents important features in the conception of the relationship between the exchange rate, inflation and the level of economic growth rate.

To study the impact of inflation targeting on exchange volatility, we use a model recently developed by Beckmann, Belke and Küh (2011) that address one methodology well known in the literature (Dornbusch (1976), Frenkel (1976), Kouri (1976). In this work, the focus will be on the emerging market, because empirical studies dealing the case of these economies are rare and the results are sometimes contradictory. To test the effect of inflation targeting on exchange volatility, we evaluate its effect on inflation, output growth and their volatilities in emerging market. For robustness reasons, our empirical study is based on the use this model. We use panel data analysis. To do that the following panel model is estimated for the sample of (N) IT ers and non IT ers countries.

For twenty years, the models developed in the literature highlight the relationship between exchange rates, prices and economic growth (Frenkel (1976), Dornbusch (1976), Bilson (1978)). These models incorporate the idea of the stability of money demand, Friedman (1976).

$\mathrm{M}^{\mathrm{D}} / \mathrm{P}=\mathrm{L}(\mathrm{Y}, \mathrm{r})$

Where $\left(\mathrm{M}^{\mathrm{D}}\right)$ is the money supply, $(\mathrm{P})$ the price level and $(\mathrm{L})$ the money demand depending on real income and (r) interest rates.
The main assumption of this model in monetary theory is that the purchasing power parity (PPA) holds, and the equilibrium is ensured by an equality relationship between supply and demand for money in the money market.

$E=P / P^{f}$

Where (E) means nominal exchange rate and $\mathrm{P}^{\mathrm{f}}$ means foreign price. The exchange rate has expressed in log-linearized form. It is expressed as the difference in price levels which is equal to the difference between domestic and foreign money supply less money demand based on money market equations. The exchange rate is determined as follows:

$E=a ́+\left(\hat{a}_{1} m-\hat{a}_{2} y+\hat{a}_{3} r\right)-\left(\hat{a}_{1}^{\mathrm{f}} \mathrm{m}^{\mathrm{f}}-\hat{\mathrm{a}}_{2}^{\mathrm{f}} \mathrm{y}^{\mathrm{f}}+\hat{\mathrm{a}}_{3}^{\mathrm{f}} \mathrm{r}^{\mathrm{f}}\right)$

$\mathrm{E}=\mathrm{a}+\hat{\mathrm{a}}_{1} \mathrm{~m}-\hat{\mathrm{a}}_{1}^{\mathrm{f}} \mathrm{m}^{\mathrm{f}}-\hat{\mathrm{a}} 2 \mathrm{y}+\hat{\mathrm{a}}_{2}^{\mathrm{f}} \mathrm{y}^{\mathrm{f}}+\hat{\mathrm{a}}_{3} \mathrm{r}-\hat{\mathrm{a}}_{3}^{\mathrm{f}} \mathrm{r}^{\mathrm{f}}$

A rise of exchange rate (E) corresponds to depreciation of the domestic currency. Then, the form presented by our model is very known in the literature by Frenkel and Bilson model (FB).Than, the terms ( $\hat{a})$ represent the elasticities and accordance with the structure of the function of money demand: $\hat{a}=\hat{a}_{1}=\hat{a}_{1}^{\mathrm{f}}=1$, where (á) is a constant term and under the original form of the model (á) is equal to zero.

(y), (m) and (r) are, respectively, the logarithms of real income, money supply and interest rates expressed in percentage.

Recently, Beckmann and al. (2011) developed the theoretical model by the restriction, that the (semi) elasticities of the interest rates are equal. Equation (4) expressed the difference between domestic and foreign money supply, real income and interest rates can be written as follows:

$E=a ́+\hat{a}_{1} m-\hat{a}_{1}^{\mathrm{f}} \mathrm{m}^{\mathrm{f}}-\hat{a}_{2} \mathrm{y}+\hat{\mathrm{a}}_{2}^{\mathrm{f}} \mathrm{y}^{\mathrm{f}}+\hat{\mathrm{a}}_{3}\left(\mathrm{r}-\mathrm{r}^{\mathrm{f}}\right)$

$\mathrm{E}=\mathrm{a}+\hat{\mathrm{a}}_{1}\left(\mathrm{~m}-\mathrm{m}^{\mathrm{f}}\right)-\hat{\mathrm{a}}_{2}\left(\mathrm{y}-\mathrm{y}^{\mathrm{f}}\right)+\hat{\mathrm{a}}_{3}\left(\mathrm{r}-\mathrm{r}^{\mathrm{f}}\right)$

Where $\hat{\mathrm{a}}_{1}, \hat{\mathrm{a}}_{2}$ and $\hat{\mathrm{a}}_{3}$ are (semi) elasticities. Than the monetary policy yield an exchange rate determination equation in this form

$\mathrm{E}=\left(\mathrm{m}-\mathrm{m}^{\mathrm{f}}, \mathrm{y}-\mathrm{y}^{\mathrm{f}}, \mathrm{r}-\mathrm{r}^{\mathrm{f}}\right)$

Indeed, according with the study of Sarno and al. (2004) and De Grauwe and Vansteenkiste (2007), the assumptions must be retained; the money market and real income are equilibrated. Uncovered interest rates parity holds and exchange with the outside must be perfectly.

\subsection{The econometric methodology data and estimations}

The empirical study is based on quarterly panel data so as to distinguish between group characteristics, respectively, of inflation targeting and non-inflation targeting emerging market. For robustness reasons, different country samples are being used. The first country sample includes the 13 inflation targeting countries. Our dataset consists of 28 emerging market examined over the period 1980:1-2013:2. According to IMF researchers, 13 of the emerging member countries had adopted IT (with flexible exchange rates) by 2007. (Called ITers or treatment group) and 15 non ITers (or control group) (see table A). Accordingly, we estimate treatment effect of IT upon macroeconomics variables by the chosen conservative starting dates of IT. Because effect of IT upon our variables is driven by the chosen starting dates of IT (see table B). In this regard, we use the exchange rates variable $\mathrm{E}$ (SDR) as a dependent variable, GDP growth representing economic activity, inflation rate (calculated with consumer price index) and Dummy indicates whether or not inflation targeting framework is employed. Countries that adopt an inflation targeting framework take one as Dummy and zero otherwise in equation. We estimate the average of inflation and output growth. The volatility of exchange rates is calculated as the standard deviation from the average. For robustness reason, we adopt two different periods (pre-targeting periods and post-targeting periods) using the approach of Ball and Sheridan (2005) by extending a standard differences-indifferences approach when we estimate two period before and 
after IT framework. Database is from the IMF (International Financial Statistics (IFS)).

\section{Estimations results}

Table 1 and 2 presents the results for all emerging market used, respectively estimation of exchange rates volatility on inflation and output growth.

The estimation results yields plausible estimates of the coefficients in the second period of estimations (after IT regime) and for the most part, the coefficients are statistically significant at conventional levels. By contrast, the analysis of the coefficients reported in the first period (before IT regime) are statistically non significant (IT dummy appears with a negative sign and no significant) providing strong evidence of the volatility of exchange rate when the (IT) regime is non-implemented. These results confirm the work of Lin (2010) and Rose (2007), which suggests that exchange rate volatility is reduced in emerging market economies. A small fluctuation of the exchange rate in (ITers) emerging market is explained by the greater ability of the Central Bank to systematically control the exchange rate. In the same context, Pontines and Siregar (2012) demonstrate that four Asian economies (Indonesia, Korea, Philippine and Thailand) whom were among the first group of emerging markets to embrace the inflation targeting framework of monetary policy, tend to adopt a form of asymmetrical exchange rate behavior, where in appreciation pressures are restrained and they concluded that the adoption of inflation targeting can lead to more flexible exchange rate movements. Specific coefficients output growth and inflation are statistically significant. these results show that the non-implementation of the policy of inflation targeting in some emerging countries do not call into question the repeated attempts of these countries to reduce inflation, using other policies (monetary aggregate targeting ) to counteract rising inflation. These results were confirmed in the work of Lin and Ye (2009), Divino (2009) and Gonçalves and Salles (2006). In other words, institutional reforms are more beneficial in emerging market, although, emerging market have suffered from periods of hyperinflation in the past which might modify results. In general, the results from using quarterly data further demonstrate confirmatory evidence of the presence of stability of exchange rate in emerging market under IT framework. The results are quite interesting. The results are quite interesting. IT significantly causes exchange rate stability. Known, stable expectations of exchange rates seem to cause negative exchange rate fluctuations. The results are similar to those Edwards (2006) and Aizenman and Hutchism (2011).

Table 1: Estimation of Exchange Rates Volatility Dependent Variable Change in the Standard Deviation of Exchange Rates between Samples

\begin{tabular}{lll}
\hline & Before IT regime & After IT regime \\
\hline Constant & $1.651^{* *}(0.74)$ & $1.71^{* *}(0.601)$ \\
IT Dummy & $-1.59(0.32)$ & $-1.263^{* * *}(0.712)$ \\
INF & $-0.185^{* *}(0.53)$ & $-1.324^{* * *}(0.88)$ \\
$\mathrm{R}^{2}$ & 0.61 & 0.78 \\
Observations & 28 & 28 \\
\hline
\end{tabular}

Source: Author's estimations.

Numbers in parenthesis are standards errors

$*, * *, * * *$ respectively denote significance at the $1 \%, 5 \%$ and $10 \%$ levels.

Table 2: Estimation of Exchange Rates Volatility Dependent Variable: Change in the Standard Deviation of Exchange Rates between Samples

\begin{tabular}{lll}
\hline & Before IT regime & After IT regime \\
\hline Constant & $1.341^{* * *}(0.907)$ & $2.41^{* *}(0.803)$ \\
IT Dummy & $-1.86(0.745)$ & $-1.13^{*}(0.981)$ \\
Output growth & $-1.232 * *(0.711)$ & $-1.553 * *(0.62)$ \\
$\mathrm{R}^{2}$ & 0.32 & 0.63 \\
Observations & 28 & 28 \\
\hline
\end{tabular}

Source: Author's estimations.

Numbers in parenthesis are standards errors

$*, * *, * * *$ respectively denote significance at the $1 \%, 5 \%$ and $10 \%$ levels.

\section{Discussion}

The success of the experience of inflation targeting in emerging countries remains relatively less favorable in comparison to industrialized countries (Lubik and Schorfheide (2007)). Our results confirm the work of Mishkin and Schmidt-Hebbel (2007). They find that (IT) in emerging markets performs less well than in advanced industrial countries, although spreads are considerable in both periods before and after inflation targeting. According to study of IMF (2005), the adoption of this monetary strategy has achieved a target inflation target that has not been achieved with other monetary strategies.

Mohantly and Khan (2004) have empirically tested modified Taylor rules for 13 emerging market. They find that the policy response to exchange rate changes is frequently larger than the response to inflation and the output gap. They suggest following an (IT) regime which guarantees the stability of exchange rates, the stability of economic growth and controlling inflation. According to the results found by Aghion and al (2009), exchange rate volatility reduces productivity in emerging market. They argued that the adverse effects of exchange rate volatility become significant in all emerging market and developing countries, which explains that the adverse effects of exchange rate volatility are more important for the less financially developed countries.

The analysis of economic developments using this method in the case of emerging countries lacks precision. Our methodology has not shown that the adoption of inflation targeting positively affects the dynamics of inflation. A new method is proposed, this is the method of evolutionary spectral analysis has been used by Ftiti.Z and Essadi.E (2013). It used to model inflation in a sample of four developed countries adopting inflation targeting. It can detect structural breaks in the series of inflation and which coincide with the economic facts (Ben Aissa, Boutahar and Jouini (2004)).

Recently some studies have focused on the comparison of the effect of inflation targeting on macroeconomic performance (Ball and Sheridan (2005), and Vega and Winkelried (2005) and l'IMF (2005)). Analyzing a group of emerging economies, Gonçalves and Salles (2008) show that IT did appear to matter for these economies.

All these studies were based on the study on cross-section evidence, but they differ in the choice of control group of non targeters, and especially in the theoretical and econometric methods used. Then, the majority of studies have interpreted the targeting of inflation as a strict monetary rule (see Gonçalves and Salles (2006) and Lin and Ye (2009)).

In our study, promising new tracks can be addressed in order to further expand the topics discussed in this work. We propose some possible extensions. The first is to further research on volatility of exchange related to de Carvalho Filho (2010). Combining developed and emerging economies, he explores the implications of inflation targeting for various economic indicators. Despite a number of studies, the question of the relative effectiveness of IT on exchange rates remains a field of research still relatively unexplored regarding emerging countries. Second, this study can be extended by studying other samples from different geographic areas. We can treat the case, for example, of the countries of emerging Europe or Latin America in order to have a more significant effect in our estimates.

\section{Conclusion}

In this study, we focus on the role of the exchange rate into the inflation targeting framework in 28 emerging market. A panel methodological approach allows us to clearly understand the importance of the exchange rate in the treatment group and allows us to distinguish them from none (IT ers) countries. We examine empirically whether or not the adoption of IT reduces volatility of exchange rates, reduced inflation and induces economic growth. Our results suggest that the adoption of inflation targeting by Central Banks in emerging market is often used with other monetary 
strategy (Aizenman and al. (2008). Our results indicate that external variables play a very important rule in the conduct of monetary policy. In this respect, Central Banks in emerging market systematically respond to the real exchange rate. Rose (2007) argues that inflation targeters have lower exchange rate volatility and (IT) is very durable regime adopted by Central Banks. Then, the results show that inflation targeting causes significantly the stability of the exchange rate. Namely, stable expectations of the exchange rate seem to cause adverse fluctuations in exchange rates, Edwards (2006) and Aizenman and Hutchism (2011).

\section{Acknowledgement}

I would like to particularly thank Pr. Daboussi (University of Chiba - Japan) for comments and suggestions.

\section{Appendix}

Table A: Country List

\begin{tabular}{|c|c|c|c|}
\hline \multicolumn{2}{|c|}{ Treatment group } & \multicolumn{2}{|c|}{ Control group } \\
\hline & & Algeria & Morocco \\
\hline Brazil & & Argentina & Hong kong \\
\hline Chile & Philippine & Bulgaria & Iran \\
\hline Colombia & South Africa & Jordan & China \\
\hline Indonesia & South Korea & India & Lebanon \\
\hline Mexico & Thailand & Tunicia & Egynt \\
\hline Peru & Turkey & Iunisia & Egypt \\
\hline Poland & & $\begin{array}{l}\text { Russia } \\
\text { Sierra Leo }\end{array}$ & Yemen \\
\hline
\end{tabular}

Source: Lin and Ye (2009) and Roger (2009)

Table B: Emerging Inflation Targeters Along with their Starting Dates

\begin{tabular}{lll}
\hline & $\begin{array}{l}\text { Soft IT: Default starting } \\
\text { dates }\end{array}$ & $\begin{array}{l}\text { Full Fledged IT: } \\
\text { Conservative starting } \\
\text { dates }\end{array}$ \\
\hline $\begin{array}{l}\text { Chile } \\
\text { South Korea }\end{array}$ & January 1991 & April 1998 \\
Mexico & January 1999 & $\begin{array}{l}\text { August 1999 } \\
\text { April 1998 }\end{array}$ \\
Brazil & June 1999 & January 2001 \\
Colombia & September 1999 & June 1999 \\
South Africa & February 2000 & October 1999 \\
Thailand & May 2000 & February 2000 \\
Peru & January 2002 & May 2000 \\
Indonesia & July 2005 & January 2002 \\
Turkey & January 2006 & July 2005 \\
Ghana & January 2007 & January 2006 \\
Philippines & January 2002 & January 2007 \\
Poland & September 1998 & January 2002 \\
\hline
\end{tabular}

\section{References}

[1] Aghion P, Bacchetta P, Ranciere R \& Rogoff K (2009) Exchange Rate Volatility and Productivity Growth: The Role of Financial Development. Journal of Monetary Economics, 56(4), 494-513.

[2] Aizenman J \& Hutchism M (2011) Inflation Targeting and Real Exchange Rates Emerging Markets. World Development, 39(5), 712 724.

[3] Ball L \& Sheridan N (2005) Does Inflation Targeting Matter? In The Inflation Targeting Debate, edited by B. S. Bernanke and M. Woodford, 249-76. University of Chicago Press for the NBER

[4] Beckmann J, Belke, A \& Kühl, M (2011) The Dollar-Euro Exchange Rate and Macroeconomic Fundamentals: A Time-Varying Coefficient Approach, Review of World Economics, 147, 11-40.

[5] Choudhri E. U \& Hakura,D S (2006) Exchange Rate Pass-Through to Domestic Prices: Does the Inflationary Environment Matter? Journal of International Money and Finance, 25, 614-639.

[6] De Grauwe P \& Vansteenkiste, I (2007) Exchange Rate and Fundamentals: A Non-Linear Relationship? International Journal of Finance and Economics 12(1), 37-54.

[7] Divino J.A (2009) The Impact of Inflation Targeting on Unemployment in Developing and Emerging Markets International Policy Centre for Inclusive Growth, WP/56.

[8] Dornbusch R (1976) Expectations and Exchange Rate Dynamics. The Journal of Political Economy, 84(6), 1161-1176.
[9] Edwards S (2006) The Relationship Between Exchange Rate and Inflation Targeting Revisited. NBER WP/12163.

[10]Frenkel J. A (1979) On the Mark: A Theory of Floating Exchange Rates based on Real Interest Differentials. American Economic Review, 69(4), 610-622.

[11]Frenkel, J A (1976) A Monetary Approach to the Exchange Rate: Doctrinal aspects and Empirical Evidence. Scandinavian Journal of Economics, 78(2), 200-224.

[12]Gagnon J.E \& Ihrig J (2004) Monetary Policy and Exchange Rate Pass-Through. International Journal of Finance and Economics, 9, 315-338.

[13] Ghosh A (2013) Exchange Rate Flexibility in Latin America. Journal of Financial Economic Policy, 5(2), 238-250.

[14]Gonçalves Carlos Eduardo S \& João M Salles (2008) Inflation Targeting in Emerging Economies: What do the data say? Journal of Development Economics, 85 312-318.

[15]Kouri P J K (1976) The Exchange Rate and the Balance of Payments in the Short Run and in the Long Run: A Monetary Approach Scandinavian Journal of Economics, 78(2), 280-304.

[16]Lin S (2010) On the International Effects of Inflation Targeting. The Review of Economics and Statistics, 92 (1), 195-99.

[17]Lin S \& Ye H (2009) Does Inflation Targeting Make a Difference in Developing Countries? Journal of Development Economics, 89, 118123. 18.

[18]Manai O. Daboussi (2014) Economic Performance and Inflation Targeting in Developing Economies. Journal of World and Research, 3 (1), 1-7.

[19]Necibi T. \& Manai O. Daboussi (2014). Exchange Rate Pass-Through as a Commitment Device under Inflation Targeting in Emerging Market. Global Journal of Research Analysis, Vol 3, Issue 4, p 43.

[20]Pavasuthipaisit R 2010 Should Inflation-Targeting Central Banks Respond to Exchange Rate Movements? Journal of International Money and Finance, 2010, vol. 29, issue 3, pages 460-485.

[21]Petreski M (2012) Output Volatilities and Exchange Rate Considerations under Inflation Targeting: A Review. International Journal of Economics and Financial Issues, 2(4), 528-537.

[22]Rose Andrew K (2011) Exchange Rate Regimes in the Modern Era: Fixed, Floating, and Flaky. Journal of Economic Literature 49, 652672

[23] Sarno L Valente G \& Wohar M E (2004) Monetary Fundamentals and Exchange Rate Dynamics under Different Nominal Regimes. Economic Inquiry, 42(2), 179-193.

[24]Sek S. K (2009) Interactions between Monetary Policy and Exchange Rate in Inflation Targeting Emerging Countries: The Case of Three East Asian Countries. International Journal of Economics and Finance, 1(2), 27-44.

[25] Svensson L (1997) Inflation Forecast Targeting: Implementing and Monitoring Inflation Targets. European Economic Review, 41(6), 1111-1146.

[26] Taylor J B (2000) Low Inflation, Pass-Through and the Pricing Power of Firms. European Economic Review, 44, 1389-1408.

[27]Wei D (2013) Do Central Banks respond to Exchange Rate Movement? Some New Evidence from Structural Estimation. The Canadian Journal of Economics, 46(2). 